\title{
Changing Bank Income Structure: Evidence from Large UK Banks?
}

\author{
Kalsoom Jaffar (Corresponding author) \\ Department of Law, Economics, Accounting and Risk \\ Glasgow Caledonian University, United Kingdom \\ Lasbela University of agriculture, water and Marine Sciences, Uthal Pakistan \\ E-mail: kalsoom.jaffar@gcu.ac.uk
}

\author{
Kumbirai Mabwe \\ Department of Law, Economics, Accounting and Risk, \\ Glasgow Caledonian University, United Kingdom \\ E-mail: Kumbirai.Mabwe@gcu.ac.uk
}

Dr. Robert Webb

Associate Professor in Banking

Nottingham University Business School, United Kingdom

E-mail: Robert.Webb@nottingham.ac.uk

Received: July 15, 2014 Accepted: Oct. 3, $2014 \quad$ Published: December 1, 2014

doi:10.5296/ajfa.v6i2.5975 URL: http://dx.doi.org/10.5296/ajfa.v6i2.5975

\begin{abstract}
The UK banking industry has steadily moved from the traditional role of financial intermediation and is increasingly relying on non-traditional business activities that generate fee income, dealings profit and other types of noninterest income. Using the dataset of large British Banks for the period 1986-2012, this study investigates the changes in the bank income structure as a result of the 1986 deregulation and tease out the effect that these changes have had in relation to systemic risk. On a micro analysis, larger banks are more able to sustain high levels of noninterest income. Among the banks Lloyds and HSBC stand out as
\end{abstract}


the major players in noninterest income generation. At aggregate level while interest income reflects a stable trend, we find a significant upward but slightly volatile trend in noninterest income for the period 1999-2008 before a sharp downturn induced by the financial crisis. This paper argues that in terms of financial stability, the banks' greater reliance on noninterest income particularly commission income is associated with higher systemic risk. This study has shown that there is a positive correlation between interest income and non-interest income for the five banks.

Keywords: Interest income, Non-interest income, Traditional banking, Deregulation diversification, Risk, bank stability, Correlation

JEL Codes: G2, G21, and G24 


\section{Introduction}

Traditionally the business of banking has been to accept deposits from customers and use these deposits to fund loans that they kept on their balance sheets until maturity. However due financial regulation that took place in the eighties, the UK banking system faced major changes in the form of increased competition, concentration and restructuring. In the context of these changes which had an impact on both the bank balance sheet and the income statements and in response to these changes, banks widened the range of products that banks offer to their customers. With regard to these changes, although the interest margin banks earn by intermediating between depositors and borrowers continues to be a source of profits for most banks, they also earn substantial amounts of noninterest income by charging their customers fees in exchange for a variety of financial services (DeYoung and Rice, 2004).

While these changing trends may be indicating this as a new development, banks have traditionally undertaken these activities even before the 1986 deregulation (Smith and Wood, 2003). However, the radical deregulation reform that became known as 'Big Bang' marked the beginning of fundamental changes for the UK banking industry by removing numerous restrictions on financial service providers. In relation to these changes, while UK banks have been shifting away from lending activities and towards broader financial services for decades, the 1986 deregulation opened the way for full financial integration by explicitly allowing financial banks to engage in a host of new activities. In the context of the changing banking environment, banks generate substantial amounts of non-interest income from non-traditional activities such as investment banking, securities brokerage, insurance agency and underwriting (Kwast, 1989; Uppal, 2011).

However, engaging in other "non-traditional" financial activities does not only give a promise for greater profitability, but also increases the industry's vulnerability to systemic risk. As indicated by Davies and Tuori (2000) the debates on the changes in the nature of financial intermediation have been mostly based on theoretical and anecdotal bases rather than empirical evidence. While several studies have examined a similar question for US commercial banks and Europe, this is the first paper to empirically examine the changing income trends in UK banks. By way interest income and noninterest income trends analysis for 5 large UK banks for the period 1986-2012, this paper explores the banks' shift from the traditional banking activities to the non-traditional banking activities using 1986 as the base year as it is after the implementation of reforms that the transformation in the bank income structure became more apparent. This article is organized as follows. Section 2 presents a brief account of related studies while section 3 presents data and methodology. In section 4 and 4.1 an empirical analysis of the interest income and noninterest income trends of all the 5 banks is presented. Section 4.2 analyses the individual bank trends and compare them to the general view while section 5 presents the correlation results between interest and non-interest income. Finally section 6 summarizes our findings and their implications before presenting a conclusion. 


\section{Related studies}

Over the past two decades there has been a substantial increase in studies investigating the combination of traditional and non-traditional banking activities. Despite the increase, earlier work on the decline of traditional banking has taken various approaches. The existing literature which is mostly based on US and in some cases on a broad set of European banks have predominantly focused on potential diversification benefits as the main reason why banks engage in a broader scope of activities. However, these studies have provided mixed results. While Eisemann (1976), Brewer (1989) and Stiroh (2002), Boyd et al, (1980) Kwast (1989) and Gallo et al, (2002) have indicated substantial benefits from diversification into non-bank activities, others have focused on the implications for stability and regulatory policy (see Edwards and Mishkin, 1995, Lui, 2012). Another cluster of research has however reported no benefits or even an increase in risk when banks combine traditional and non-traditional activities( see Stiroh and Rumble,2006; Boyd and Graham, 1986). Boyd and Graham (1986) found that expansion by bank holding companies into non-traditional; banking activities increased the risk of failures during less stringent policy periods in the 1970s. In the same context Demsetz and Strahan (1995) also indicate that no risk reduction was observed as banks tended to move to riskier activities to lower their capital ratios.

DeYoung and Roland (2001) in their study on non-interest income and financial performance at US commercial banks found that fee-based activities increase the volatility of bank revenues. These findings are also similar to the work of Stiroh (2004) and Stiroh and Rumble (2006) who not only show that non-interest income is more volatile but argue that it is also increasingly correlated with interest income. These findings imply lower diversification benefits which Stiroh (2004) and Stiroh and Rumble (2006) have argued could be due to possible cross selling of different products to the same customers.

Smith and Wood (2003) examine the variability of interest and non-interest income, and the correlation between these two variables, for the banking systems of EU countries for the period 1994-1998 and in the process arguing that non-interest income reduces bank risk via diversification. They found the increased importance of non-interest income to stabilise profits in the European banking industry in those years. Further, Canals (1993) found that the increased revenues obtained from new business units have significantly contributed to improving bank performance. Focusing on the impact of non-interest income on bank profitability, Saunders and Walters (1994) argue that fee-based income stabilises profitability. This was also supported Uppal (2011) who argues that after reforms banks have start to enter the financial market with almost daily innovative products/services to capture maximum market share and then earn maximum profits. Uppal (2011) argue that the combination of banking, insurance and securities activities may lead to a more stable profit stream since the revenues stemming from different products in a conglomerate organisation are usually imperfectly correlated.

In another strand of research, Mester (1992) found that mixing traditional banking activities of originating and monitoring loans with non-traditional activities of loan selling and buying products does not only lead to economies of scale but also diseconomies of scope. Further, 
researchers Kwast (1989), Mishkin (1999), Chow and Surti, (2011) and Hale and Santos (2009) argued that the shift from traditional banking to non-traditional banking where banks borrow short, lend long and hold on to loans as an investment has been reshaped by increased competition and innovation after the deregulation of banking in 1986. Deregulation which aimed to increase competition and profitability of banks dramatically changed characteristics of the bank balance sheet, from the types of assets bank hold to how they fund themselves to the source of bank income.

Bord and Santos (2012) provide an account of how banks adopted the originate-to-distribute model in their corporate lending business and provide evidence of the effect that this shift has had on the growth of nonbank financial intermediation. Thus, the originate-to-distribute model has changed the credit intermediation as these functions now occur less on bank balance sheets and more in capital markets. As the profitability of traditional banking activities has, for a wide variety of reasons, come under pressure in recent years, fee-earning activities have greatly increased their contribution to bank profits. Further, Lepetit et al, (2007) indicated that as a result of deregulation and the adoption of universal banking principles commercial banks can compete on a wider range of market segments. Additionally, Hale and Santos (2009) are of the view that banks no longer hold the loans they generate and originate as investment but sell these loans to brokers to get liquidity and increased fee income. However, these in turn pool banks to issue securities which are distributed to a range of investors with a different set of risk characteristics. Thus, with the shift to noninterest income came a different set of risk characteristics that pose a threat to financial stability as was witnessed in the 2007-2010 financial crisis (Griffiths, 2011).

An alternative way of viewing the banks' shift to non-traditional banking activities is by looking at the size of the banks' balance sheet in relation to the balance sheets of other financial intermediaries (Edwards and Mishkin, 1995). In this context, a reduction in balance sheet size is observed. However, as argued by Boyd and Gertler (1994) and later by Edwards and Mishkin (1995) the reduction in bank balance sheet size of the banking industry is not an indication of a decline in banking industry but an increase in off-balance-activities. This is in support of Kaufman and Mote (1994) and Smith and Wood (2003) who argue that the banking industry is not actually declining in any meaningful economic sense; rather, the nature of its intermediation activity is changing and is now dominated by the originate-to-distribute model.

A further issue to consider in relation to changing bank income structure is the issue of measurement. The measurement of the shift from traditional banking activities to nontraditional banking activities is not clear cut. Edwards and Mishkin (1995) argue that the standard measures of profitability such as pre-tax rates of return on assets and equity do not provide a clear trend in bank profitability as overall bank profitability includes increasingly important non-traditional business of banks. This paper build on Edwards and Mishkin's (1995) study and Davies and Tuori's (2000) argument that the income structure is considered to be a particularly fruitful area to look for indications of changes in the nature of the banking industry. We use the crude measure of profitability where we single out noninterest income from total earnings since much of this income comes from non-traditional activities. 
From a bank safety and stability perspective, numerous studies have investigated the implications that the adoption of universal banks have on bank risk, the safety and soundness of the banking system as well as the implications for the supervisory authorities (See: De Young and Roland, 2001; Stiroh and Ruble, 2004). Stiroh and Rumble (2006) argue that when banks move into fee income earning activities, sometimes the diversification gains are more than offset by the costs of increased exposure to volatile activities and this represent the dark side of diversification and this has implications for supervisors, managers, investors and borrowers. However the authors argue that in the US banks are now aware of the limitations of the expansion into non-traditional banking activities and are reverting back to the core banking competencies and in the process avoiding products that adversely affect their bottom line.

While much work has been done on the decline of traditional banking and the analysis of interest income and noninterest income in the US, this is the first study in the UK to examine the interest income and noninterest income trends that covers the periods since the 1986 deregulation as well as the recent financial crisis. We also follow Edwards and Mishkin's approach although several important features differentiate the current paper from earlier work analysing the trend from a different viewpoint. We use large UK bank financial statement data from 1986 up to 2012. We notice a significant shift from interest income to non-interest income beginning from as early as 1999 for some banks. We conduct a correlation analysis which enables us to capture the correlation between interest income and non-interest income for the period of our study and focus on the risk implications for the regulators and the banking industry at large.

\section{Data, Methodology, and Sample}

The empirical analysis uses data on revenue sources for UK bank and bank holding companies (BHCs). This section defines the key variables in the analysis and provides some discussion of their relevance and importance. The current study focuses on five major British banks namely, HSBC, Royal Bank of Scotland, Lloyds, Barclays, and NatWest. We utilise data from annual reports including balance sheet and income statement. Our choice of these banks is based on the fact that they play an essential role in the economy of the UK and contribute a huge percentage in the GDP of the country. The sample data is from 1986 to 2012 with $1986^{1}$ as our starting point as it was dubbed as "Big Bang" when the deregulation of financial markets allowed banks to expand their activities in order to increase competition, innovation and profitability. Our main focus is to critically analyse the changes in interest and non-interest income thereby providing an account of the changes in the income structure in the banks as a result of the deregulation and tease out the contribution that these changes have had to bank performance and systemic risk compared to a period when banks only focused on traditional banking interest income activities.

\footnotetext{
${ }^{1}$ RBS and Natwest only started reporting non- interest income in 1994 and 1992 respectively
} 


\section{Mll Macrothink}

\section{Empirical results}

\section{Broad Overview}

The main aim of this study is to investigate the changing bank income structure with particular emphasis on interest income and noninterest income for the 5 large UK banks. Although the data indicate that UK banks increasingly shifted from traditional banking from as early as 1986, we find this trend more significant from 1999. In 1986, the first year of our sample, the banks' non-interest income was $£ 2265$ million. However, in 2007, non-interest income had risen to $£ 9548$ million. By 2008 however as a result of the financial crisis, non-interest income had fallen to $£ 5659$ million. The interest and non-interest income trends for the period 1986-2012 are shown in Figure (1) below.

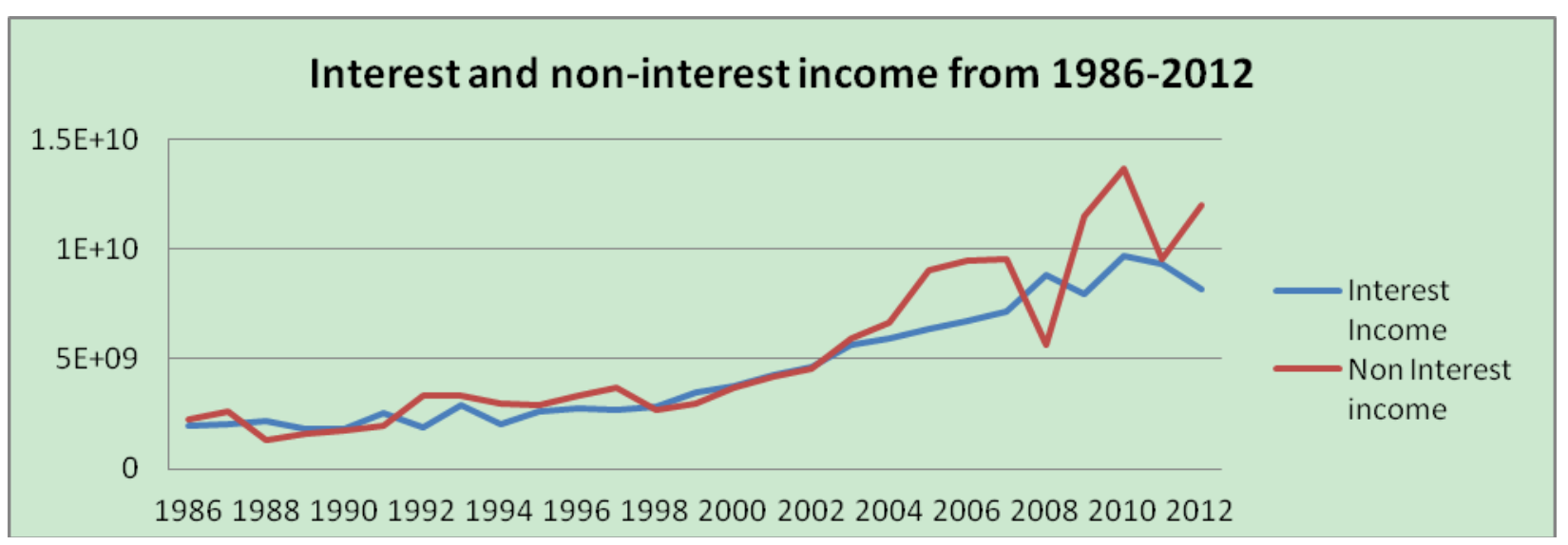

Figure 1. Interest and noninterest income of UK banks from 1986-2012

As shown in Figure (1) the noninterest income for the period 1986-1988 increased due to deregulation of banking sector by the Thatcher government to increase competition and profitability as banks which were not reporting the noninterest income started reporting the income from 1986. As Davies and Tuori (2000) highlighted, noninterest income is associated with more volatile bank returns which is observed in 1989 when the banking sector faced a downturn hence the noninterest income fell by $50 \%$ in 1991 . The trends indicate that banks significantly diverted attention towards diversifying and investing in non-interest generating activities over the period as illustrated by Figure (2) which shows the proportion of interest and non-interest income operating profit of banks. 


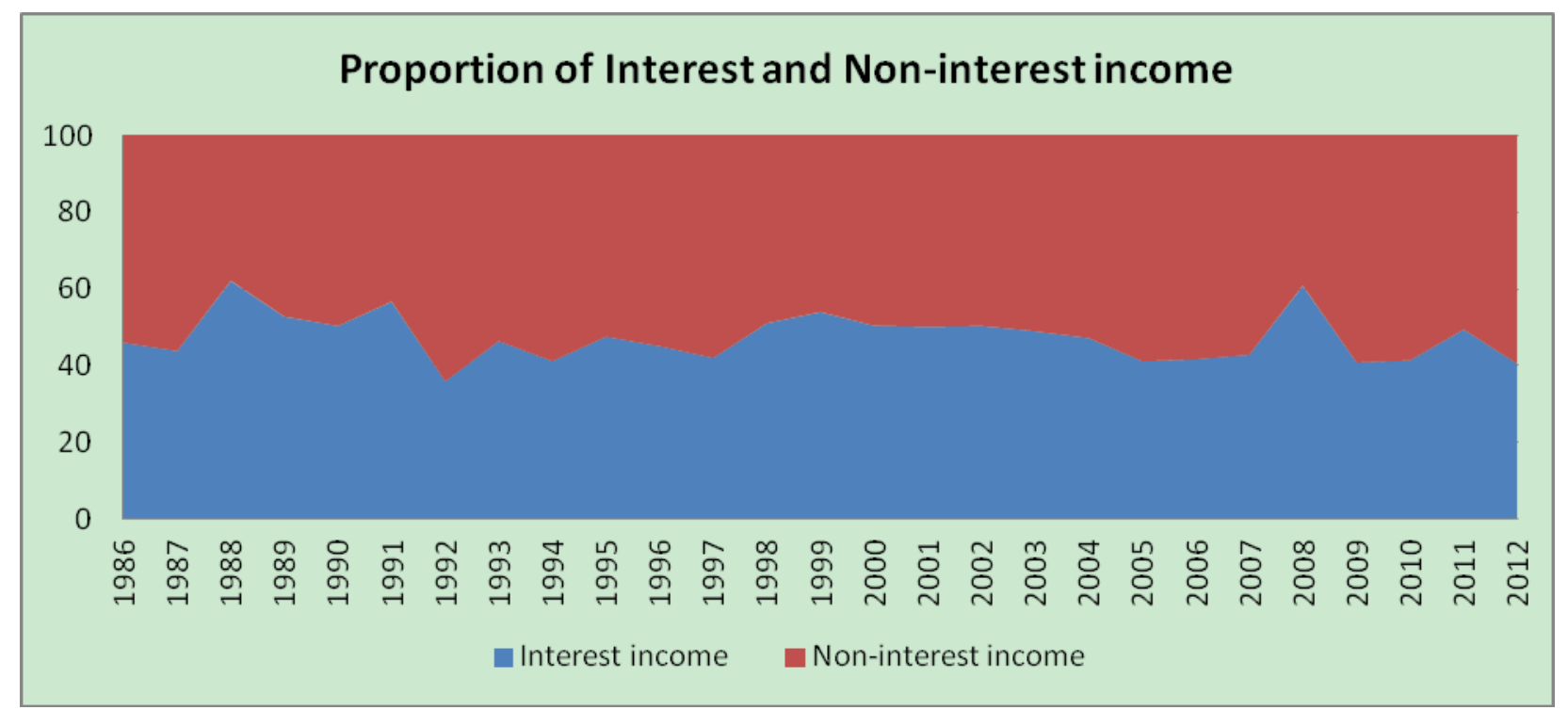

Figure 2. Proportion of Interest income and non-interest income in operating income

On an individual bank basis Lloyds stands out when compared to other banks. HSBC and RBS show an upward movement however NatWest and Barclays shows a stable upward movement from 1986-2012 as shown in Figure (3) Appendix A.

In contrast, a significantly stable trend was observed in the banks' interest income. The interest income for Lloyds was lower compare to the noninterest income trend as seen above in Figure (3 \& 4) in appendix. RBS shows completely different troughs although compare to HSBC as these two banks display similar trends in non-interest income.

The results are in support of Brunnermeier et al, (2012) who indicated that banks with high interest income contribute more to systemic risk than banks with lower interest income. Our analysis reveals a similar trend as banks with higher noninterest income such as Lloyds had major losses during the financial crisis 2007-2008. Banks, after the deregulation act in 1986, moved from their traditional role where short term funds and lending occurred on bank balance sheet and loans were held on to as an investment. This meant that the systemic risk that were impossible to diversify were hedged by the liquid assets but in originate to distribute model of banking banks started to sell those loans and then securitized in asset backed securities, and might even re-securitised and these were held off-balance sheet. The main argument by Bord and Santos (2012) is when banks became more involved in originate to distribute model which allowed credit risk to be sliced, diced and dispersed but allowed them to earn fee income however, that exposed banks to systemic risk.

Non-interest income increased by only $8.37 \%$ in 1999 however a 39\% increase in 2001 is observed, this is when non-interest income became a major source of income for banking sector. Moreover, in 2003 the noninterest income increased by $48 \%$ as compare to 2001 . The noninterest income followed an increasing trend up to 2007 as compare to interest income which was increasing but at a decreasing rate. Thus we observe that noninterest income increasingly became the major source of income for banks. 
Following the increasing trend up to 2007 the results of the analysis show a significant downturn in the non-interest income consequent of the 2007-2010 financial crisis. The noninterest income fell by $41 \%$ from $£ 9548$ million in 2007 to $£ 5659$ million in 2008 . In contrast, the interest income increased by $18 \%$ from $2007-2008$ but decreased by $9.5 \%$ from 2008-2009. This justifies ECP (2000) argument that non-interest income does not seem to be less volatile than interest income. The selected bank non-interest income is predominantly securities income and other income where the income from securities is more volatile than fee and commission income. The reason behind the decrease in interest income was due to the fact that the mortgage products were rapidly being pulled from the market due to losses on loans bad debts being written off which reduced the interest earned on the mortgage. The volatile nature of non-interest income pushed it to fall rapidly during this time.

As indicated by literature above some of the changes in bank income structure were due to technological changes as well as financial processes. Due to the 2007-2010, financial crisis consumer confidence fell to a record low and in the process reduced consumer demand for loans which ultimately reduced banks interest income as from 2008. As highlighted by Edwards and Mishkin (1995) and later by Bord and Santos (2012) the increase in originate to distribute function of banks and declining role of banking in traditional financial intermediations is based on comparison of the bank balance sheet size relative to other financial intermediaries. However, as argued by Boyd and Gertler (1994) the decline in the share of total financial intermediary assets does not indicate that the banking industry is in decline but a switch to the non-traditional banking activities.

\section{Interest income and Noninterest income trends for individual banks}

Traditionally, fee income or non-interest income was a small part of the earnings stream of most banks. However, the earning stream in banks is affected by changes in other factors such as interest receivable, payable and expenses, the effect of these are discussed in relation to Lloyds (see: Figure (3) in Appendix).

The non-interest income in Lloyds was greater than interest income in 1986 and remained higher until 1988 where interest non-income was $£ 687.5$ million and interest income was $£ 192.6$ million (Appendix Figure 5). The decline of interest income is not unique to Lloyds, but was due to the banks being hard hit by the recession from 1988-1992. Moreover, a drop in both interest and noninterest income can be seen from 1989-1994 when the banking sector was in turmoil during the LTCM crisis. A major event in the shift from traditional activities for Lloyds bank is noticeable with the increase in noninterest income that follows the merger with Abbey Life in 1988. This brought about a slight increase in both interest income and noninterest. In 2000 the bank acquired Scottish Widows (a mutual life assurance company). This made Lloyds the second largest UK provider of life assurance and pensions. Scottish Widows contributed an income of $£ 403 \mathrm{~m}$ as of March 2000. Consequent of the purchase the group fee income increased to $46 \%$ of total income compared to $40 \%$ of 1999 .In the same year the bank purchased Chartered Trust from Standard Chartered to form the Lloyds TSB Asset Finance Division which provides motor, retail and personal insurance under the name Black Horse. Consequently income contribution from insurance and investments rose to $34 \%$ of total income. 
Hence the upward trend in noninterest income continues to be noticeable. In 2004 the noninterest income was $75 \%$ higher than interest income. This increase in noninterest income was due to an increase of $£ 26$ million in fee and commission receivable which relate to a wide range of services provided throughout the group.

As a result of the investment in Scottish Widows and the operations of Black Horse the bank witnessed a significant increase in noninterest income for the period 2000-2004. This was backed by a strong growth in income from insurance broking, card services and other short term investment. The interest income comparatively is showing a stable trend over the period however, as Hale and Santos (2009) argued the noninterest income is more stable than interest income and fee based activities reduce bank risk via diversification. The increase in noninterest income is also due to increased bank investment on other financial instruments rather than just making loan to customers.

For Lloyds in relation to the changes on the balance sheet flowing through to the income statement the results of this study show that with a decrease in the percentage of loan to customers as a proportion of total assets came an increase in the noninterest income for the bank. This trend is observed for the period from 1996-2007. However, a totally different trend is observed during the 2007-2010 financial crisis when the percentage of loan decreases due to reduced demand of loans. Thus the interest and noninterest income both declined due to low demand of loans and other marketable securities and the bank writing off loan losses.

With regard to the relationship between increase in non-interest income and bank profitability of particular significance is HSBC where the increased revenue obtained from 'new' HSBC businesses increased the profitability of the bank. As illustrated by Figure (7) (Appendix). The bank started with a balanced mix of interest and noninterest income from 1988 where the interest income was $£ 1721$ million and noninterest income was $£ 1137$ million. Although non-interest earning activities slightly decreased during 1991-1996 when the banking system in the UK was facing a downturn HSBC's interest income in the 1987 reflects a high level of average assets and the interest margin of the bank was slightly higher than 1986 due to improved interest spread and increased proportion of mortgage loans. Despite the flat tariff structure in the UK in 1987, HSBC's noninterest income increased by $12.5 \%$ due to growth in banking commissions.

HSBC continued to expand the insurance and trust business which leads to increased commission income. Interest income in 1991 grew by $£ 1757$ million as compared to $£ 1643$ million in 1990 while noninterest income increased by 5\% from 1990-1991. These results are in support of Gallo, Apilado and Kolari (1996) found that the high proportion of mutual assets of banks holding companies over the period of 1987-1994 was associated with increased profitability and reduced risk for bank holding companies.

Dealing profits increased due to increased securities trading profit. The trading profit, fee income and commission increased with growth in First Direct, cards and Griffin Factors. The noninterest income in 1997 was 8\% higher than interest income which decreased to 4\% in 1998.After 1998 HSBC's fee income grew from $£ 1275$ million to $£ 1488$ million in 1999 reflecting strong wealth management activities. In 2001, the interest income increased to 
$£ 3325$ million from $£ 2716$ million in 2000 due to growth in personal and commercial current account saving and lending in the UK banking. The non- interest income in 2000 was also increasing due to strong growth in global safe custody fee, higher current account and overdraft fee and increased corporate banking fee. Noninterest income in HSBC UK banking was driven by an increase of $16 \%$ in life, pension and investment income and $7 \%$ increase in general insurance income.

HSBC derived an increasing share of their profit from off-balance sheet activities such as fee income, commission, insurance and other trading activities. As a share of total bank income, the noninterest income increased from 42\%, in 1990 to 48\% in 1991. A declining trend can be observed in bank's interest income and the declining trend in profitability of bank's traditional business becomes evident with the noninterest income stable over the period until it takes a slight downturn from $89 \%$ to $69 \%$ observed in $2008-2009$. The decline in interest income was attributable to lower yield on excess liquidity and customer lending partly offset by reduction is cost of funds on customer accounts.

When compared to Lloyds and HSBC, NatWest shows a different story with noninterest income in NatWest higher than interest income from 1992 through to 2000 as shown in Figure (9) (Appendix). The income trend for NatWest is stable as compare to that of HSBC and Lloyds. This may be due to what Mishkin (1999) labelled as financial innovation and deregulation that created attractive alternatives for both depositors and lenders and banks as well. After the deregulation period NatWest doubled the share of their income from off-balance sheet, noninterest income activities. However, the bank only started to report the interest income and noninterest income in their financial reports from 1993. However, a review of the banks' annual statements and augmentation ${ }^{2}$ with other information shows that the interest income of the bank accounted for $62 \%$ of total income in 1988 and the steady increase in income is not only from increased volume of business but effective management of interest rate exposure during the period when interest rates have fluctuate significantly. In the same breadth noninterest income grew by $68 \%$ since 1984 and kept pace with the increase in interest income over the same period.

In 1990 interest income increased by 3\% while noninterest income rose by $9 \%$ despite the downturn in economic activities in major markets of the group. Commission income which is the main component of noninterest income rose by $16 \%$. Although the investment banking business of NatWest was affected by the deterioration in world stock markets and the UK economy in 1993 noninterest income of the bank benefited from the launch of National Westminster Life Assurance (NatWest Life) and increased popularity of card and electronic payment system. In the same breadth the interest income increased due to increase in home loans in 1993 subsequently, fall in 1994 due to subdued loan demand. Overall, interest and noninterest income trends were largely stable over the period of 1995-2005 however a significant decrease can be observed in 2008-2009 when the noninterest income falls from $£ 5397$ million to $£ 3197$ million.

\footnotetext{
2 Augmentation with the directors reports
} 
Generally, for the period of 1986-2012, noninterest income in NatWest was 51\% of total income which is higher than interest income which constituted only $49 \%$. The increase in noninterest income is due to increased engagement in unlimited derivatives activities, and other debt and equity securities as shown in Figure (10) in Appendix.

The asset side of NatWest balance sheet shows that the bank invested a significant amount of funds in debt securities other investing assets include derivatives, equity securities, and dealing assets as shown above in Figure (10) in Appendix. For NatWest the results of the research are in support of Edwards and Mishkin (1995) reported that banks have increased their participation in derivatives markets dramatically in the last few years. They further argue that these derivatives are held by large banks primarily to facilitate their dealings and trading operations. This increased participation of banks in derivatives markets has been a concern for both regulators and legislators because derivative will enable banks to take more risk than is prudent. Researchers (Kashia, Rajang and Stein, 2002, Mishkin, 1999) argue that such activities are riskier than traditional banking activities and could threaten the stability of the entire banking system. Further, as argued by Edward and Mishkin (1995) derivative are often complex instruments and need sophisticated risk control system to measure and track the potential exposure of bank.

Barclays shows a totally different trend due to its huge involvement in investment banking operations. Figure (11) in Appendix shows the interest and noninterest income trend of Barclays over the period of 1986-2012. As from 1986, there was a strong performance from central retail services division interest income has steadily increased since 1982 by an average annual rate of $11 \%$. The non-interest income increased from $£ 1785$ to $£ 2966$ in 1988 which was an increase of $42 \%$ where money transmission and lending fee made important contributions. The interest income increased to $£ 3420$ million in 1989 due to stronger balance sheet growth, increase in interest rate earning assets to $12 \%$ in 1987 as compare to $7 \%$ in 1986 . It can also be argued that this increase was due to falling interest rates in both 1987 and 1986. Furthermore, the interest income increased in 1987 and 1988 by $11 \%$ and $8 \%$ respectively due to growth in lending in the domestic UK banking. The interest income came under pressure in the second half of 1988 due to increase in interest rates. Noninterest income improved by $15 \%$ in 1988 however, the contribution of noninterest income was $38 \%$ of total income compared to $37 \%$ in 1987.

For noninterest income, commission in particular increased by $12 \%$ in 1989 . However, a drop in both interest income and noninterest income is observed in 1994 due to $2 \%$ reduction in gross fees and commission due to decline in lending fee because of lower volumes. Interest income in 1998 increased as compare to noninterest income due to maintained overall deposits and lending levels. However, a stable interest and noninterest income trend is observed till 2012 with a slight drop in noninterest income in 2005. Barclay's investment banking arm was considered as a primary source of increase in noninterest income due to increased commodity products and improved performance. However, interest income remained constant in 2011-2012 notwithstanding the group facing a decline in interest margin due to reduced benefits from group structural interest rate and hedging activities. 
RBS follows a slightly different trend when it comes to interest and noninterest income from 1994-2012 as shown in the Figure (12) in Appendix (the Figureure shows the data from 1994 because RBS started reporting non-interest income in 1994). The interest income and noninterest income steadily increased over the period of 1994-2000. An increase in noninterest income is evident in 2003 where noninterest income is 19\% higher than interest income which further became equal to noninterest income in 2005. From 2001-2007 non-interest income is significantly higher than interest income. A significant fall in noninterest income is observed in 2008 where noninterest income fell from $£ 11191 \mathrm{~m}$ in 2007 to $£ 2348 \mathrm{~m}$ in 2008 due to the financial turmoil all over the world, the demand for marketable securities reduced and due to increased mortgage default commission fee reduced. Total income of the bank increased by $3 \%$ in 2007 where interest income increased by $7 \%$ but commission payable increased by $5 \%$ to $£ 1469 \mathrm{~m}$. The reason behind the decline in noninterest income was due to a $55 \%$ decrease in trading activities due to write-down reflecting the weaknesses in US housing market. The interest income fell by $7 \%$ to $£ 11298 \mathrm{~m}$ due to run off balances, high risk segment in no core and exit of higher margin. Additionally this is due to the fact that compared to other banks RBS was highly exposed to the housing market due to the nature of its operations. The noninterest income decreased to $£ 10508 \mathrm{~m}$ from $£ 11593 \mathrm{~m}$ in 2010 . The noninterest income of the bank also decreased in the first quarter of 2012 which reflects lower gains in non-core income as investors' confidence waned and lower international client activities. These results are in line with the KPMG (2012) UK banking performance report which indicates that this decrease in RBS's noninterest income can also be due to decreased card transaction volume and the impact of exit of certain businesses from insurance businesses.

Overall, as indicated in literature and as discussed above, the increased importance of fee income at commercial banking companies is a direct result of structural changes such as industry deregulation. However the impact of new information technologies and financial innovation cannot be disregarded. The relationship between interest income and non-interest income is explore in more detail in the next section.

\section{Correlation Analysis:}

In this section we examine the correlation between interest income and non-interest income in UK banks after deregulation from 1986-2012 to investigate the effect of the banks shift towards non-traditional banking activities which have resulted in significant increase in noninterest income. The first table present the descriptive statistics while table 2 presents the results of the regression.

Table 1. Summary statistics

\begin{tabular}{lll}
\hline Variable & Mean & Std. deviation \\
\hline Interest Income & 3545619382.716 & 1987398802.739 \\
$\begin{array}{l}\text { Non-Interest } \\
\text { income }\end{array}$ & 3851142777.778 & 2190002242.222 \\
\hline
\end{tabular}


The correlation between interest and non-interest income is displayed in table (2) below

Table 2. Correlation matrix (Pearson)

\begin{tabular}{lll}
\hline Variables & Interest Income & $\begin{array}{l}\text { Non-Interest } \\
\text { income }\end{array}$ \\
\hline Interest Income & $\mathbf{1}$ & $\mathbf{0 . 9 4 1}$ \\
Non-Interest income & $\mathbf{0 . 9 4 1}$ & $\mathbf{1}$ \\
\hline
\end{tabular}

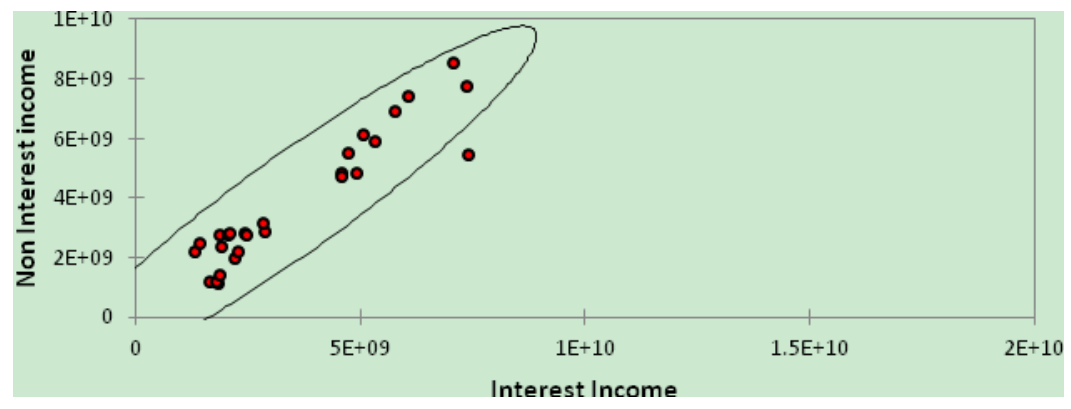

Figure 13. Correlation between interest and non-interest income

The results of this study indicate that for the UK banks interest income and non-interest income are highly positive correlated. The correlation indicates that a unit increase in interest income increases the non-interest income by 0.941 units. This high correlation between selected variables shows that the major UK banks are shifting predominantly from interest income to non-interest income. The non-interest income is increasing and at the same time interest income is increasing at a decreasing rate. It is difficult to explain these results but a possible explanation may be that banks may be changing the way they conduct traditional banking activities consequent of the increased competition from other non- banking institutions, building societies and finance house after deregulation which increases interest income. In this context to meet this competition banking sector was required to be re-oriented to be in tune with global market and consumer demands. Hence in order to meet the challenges of competition from non-banking financial institutions, banks have started to restructure their business and in the name of innovative products started selling the loans by packaging them through securitisation which ultimately adds to non-interest income. This supports the views shared by Uppal (2011).

The non-interest income is composed of many possible income streams such as fee income, commission and the returns on trading assets which could increase even if banks are focusing more on traditional role of borrowing and lending. Our results are in support of DeYoung and 
Rice (2004) who suggested that banks earn non-interest income by producing both traditional banking services and non-traditional financial services. In relation to diversification and the lower diversification benefits our results are in support of Stiroh (2004) and Stiroh and Rumble (2006) who argue that argued the correlation between interest and non-interest income could be due to possible cross selling of different products to the same customers. We argue that with regard to UK banking universal banking principles does not only reflect diversification into non-traditional banking activities but also a shift in the way banks earns money from their traditional banking activities. Our results show that banks derive non-interest income not only from traditional charges such as checking and cash management but from new sources such as cash withdrawal, bank account management and insurance provision on banking products, online bill payment and underwriting. These results are in line with DeYoung and Rice (2004:35) who also found "payment services-one of the most traditional of all banking services- remain the single largest source of non-interest income at most US banking companies'. The evidence from this study suggest that banks are earning non-interest income from both traditional banking activities and new non-traditional banking business. Hence, there is a positive correlation between interest income and non-interest income.

\section{Final Remarks and conclusion}

The objective of this study was to analyse the risk implications of the UK banks' shift towards non-traditional banking activities. On the basis of the chosen parameters the study concludes that interest income though increasing: it is increasing at a decreasing rate and non-interest income is rising since (the Big Bang) deregulation in 1986. What became evident from this research is that banks do more than intermediate between depositors and borrowers: they are not limiting themselves to simply earning net interest margins but they have moved to be 'stylized general financial supermarkets' with the adoption of universal banking principles as evidenced by the remarkable increase in non-interest income. Significant increases in non-interest income were not only made possible by deregulation in 1986 but as argued by DeYoung and Rice (2004) for some banks increases in non-interest income were also made possible by advances in information technology, communication channels and financial processes.

Our study of the change in banks' focus from traditional activities to non-traditional activities yields a number of significant findings. Firstly, the present study, makes several noteworthy contributions to the literature. On the data side, we examine the consolidated bank holding company (BHC), rather than the subsidiary bank. Secondly, the correlation proved that banks are fulfilling the requirements of regulators to focus on traditional banking by generating interest income however, the positive association between interest and non-interest income proves that banks are still more interested in generating diversified income streams rather than focusing on traditional banking methods of income generation.

Further, the results of the study indicate non-interest income is much more volatile than interest income from our global view point and for each individual bank. We also found that interest income increases while non-interest income also increases as evidenced by the results of the regression. Possible explanation for these results is: UK banks shifting the way they 
make money from traditional banking activities. Another possible explanation for these results is that UK banks subsequent to the financial crisis and the government rushing them to lend are still generation a substantial amount of non-interest income by using non-traditional methods to produce traditional banking. These thoughts are also shared by DeYoung and Rice (2004) who argue that in the traditional banking model loan servicing fees and securitisation do not exist, as banks originate these loans in their own portfolios and service these loans themselves. We extend the work of DeYoung and Rice (2004) and argue that banks should not be using their loan books to generate non-interest income from customer deposits as this exposes banks to systemic risk. Our argument is based on Boyd and Graham (1986) who earlier on ( even before deregulation) found that banks' increased activity in non-traditional banking activities increased the risk of failures during less stringent policy periods in the 1970s.

The trends documented in this article have important implications for banks and the regulators. Banks' increasing diversification to non-traditional activities has implications for financial stability and exposes the industry to systemic risk. While banks may respond to their shrinking intermediary role and diminished profitability by taking greater risk, if this goes unrestrained, it could undermine the stability of the banking system. The financial crisis provided some evidence that banks have in fact increased their risk-taking, either through riskier strategies in their traditional business lines or by seeking out new and more risky activities which left the whole banking industry exposed to greater systematic risk. In the process, this scenario has contributed to the growth of financial intermediation outside the banking system, including a larger role for unregulated "shadow banking" institutions (Piciu et al., 2011). A constructive regulatory approach by the regulator has been to adopt a system of structured bank capital requirements together with early corrective action by regulators. However this only works if bank risk exposures have been measured accurately and capital requirements be set high enough to deter excessive risk-taking and for the regulator to adapt their policies to the new financial environment. This strategy, we believe, can successfully keep in check excessive risk-taking by banks while providing the flexibility for both banks arid regulators to restructure the banking system in order to achieve greater long-term stability. In the UK this is developing in the form of Independent Commission of Banking's report key recommendation: ring-fencing retail operations. Based on our results, we support this contention in the perspective of the UK banking industry and argue the loan portfolio and the investment portfolio should be kept separate. These arguments form the basis of future research.

\section{References}

Brewer, E. (1989). Relationship between bank holding company risk and non-bank activity, Journal of Economics and Business, 1(4), 337-53. http://dx.doi.org/10.1016/0148-6195(89)90030-1

Brunnermeier, K., M., Dong, G., \& Palia, D. (2012). Banks' noninterest income and systemic risk', Chicago Meetings Paper. http://dx.doi.org/10.2139/ssrn.1786738

Bord, V. M., \& Santos, J. A. (2012). The rise of the originate-to-distribute model and the role of banks in financial intermediation. Federal Reserve Bank of New York Economic Policy Review, 18(2), 21-34. 
Boyd, J. H., \& Gertler, M. (1993). US commercial banking: Trends, cycles, and policy. In NBER Macroeconomics Annual 1993, 8, 319-377). MIT Press. http://dx.doi.org/10.2307/3585037

Canals, J. (1994). Competitive strategies in European banking. OUP Catalogue. http://dx.doi.org/10.1093/acprof:oso/9780198773504.001.0001

Chow, J. T. (2011). Making banks safer: can Volcker and Vickers do it?. International Monetary Fund.

Davis, E. P., \& Tuori, K. (2000). The Changing Structure of Banks' Income: An Empirical Investigation. Brunel University, Department of Economics and Finance.

DeYoung, R., \& Rice, T. (2004). How do banks make money? The fallacies of fee income. ECONOMIC PERSPECTIVES-FEDERAL RESERVE BANK OF CHICAGO, 28(4), 34.

Edwards, F. R., \& Mishkin, F. S. (1995). The Decline of Traditional Banking: Implications for Financial Stabilityand Regulatory Policy (No. w4993). National Bureau of Economic Research. http://dx.doi.org/10.3386/w4993

ECP (2000). 'EU Banks income structure', European Central Bank, Available at; https://www.ecb.europa.eu/pub/pdf/other/eubkincen.pdf

Eisemann, P. (1976). Diversification and the congeneric bank holding company. Journal of Bank Research, 7(1), 68-77.

Gallo, J. G., Apilado, V. P., \& Kolari, J. W. (1996). Commercial bank mutual fund activities: Implications for bank risk and profitability. Journal of Banking \& Finance, 20(10), 1775-1791. http://dx.doi.org/10.1016/S0378-4266(96)00024-6

Griffiths, K., (2011). If we must ring fence retail banking, this is how it should be done, say big banks. The Times Section 42.

Hale, G., \& Santos, J. A. (2009). Do banks price their informational monopoly?. Journal of Financial Economics, 93(2), 185-206. http://dx.doi.org/10.1016/j.jfineco.2008.08.003

Kashyap, A. K., Rajan, R., \& Stein, J. C. (2002). Banks as liquidity providers: An explanation for the coexistence of lending and deposit-taking. The Journal of Finance, 57(1), 33-73. http://dx.doi.org/10.1111/1540-6261.00415

Kwast, M. L. (1989). The impact of underwriting and dealing on bank returns and risks. Journal of Banking \& $\quad$ Finance, 13(1), 101-125. http://dx.doi.org/10.1016/0378-4266(89)90022-8

Kaufman, G. G., \& Mote, L. R. (1994). Is banking a declining industry? A historical perspective. Economic Perspectives, (May), 2-21.

KPMG, 2012, Annual report 2012, Available at: http://www.kpmg.com/EU/en/Documents/kpmg-annual-report-2012-new.pdf 


\section{Macrothink}

Asian Journal of Finance \& Accounting ISSN 1946-052X

Lepetit, L., Nys, E., Rous, P., \& Tarazi, A. (2008). Bank income structure and risk: An empirical analysis of European banks. Journal of Banking \& Finance, 32(8), 1452-1467. http://dx.doi.org/10.1016/j.jbankfin.2007.12.002

Lui, A. (2012). Retail ring-fencing of banks and its implications. Journal of Banking Regulation, 13(4), 336-348. http://dx.doi.org/10.1057/jbr.2011.27

Mester, L., (1992). 'Traditional and non-traditional banking: an information-theoretic approach', Journal of Banking and Finance, 6(3), 545-66. http://dx.doi.org/10.1016/0378-4266(92)90044-Z

S Mishkin, F. (1999). Financial consolidation: Dangers and opportunities. Journal of Banking \& Finance, 23(2), 675-691. http://dx.doi.org/10.1016/S0378-4266(98)00084-3

Piciu, G. C., Chitiga, G., Mihaila, N., \& Trica, C. (2011). The Decline of Traditional Banking Activities. EIRP Proceedings, 6 .

Smith, R., Staikouras, C., \& Wood, G. (2003). Non-interest income and total income stability (p. 37). Bank of England.

Saunders, A., \& Walter, I. (1994). Universal banking in the United States: What could we gain? What could we lose?. OUP Catalogue.

Uppal, R. K. (2011). fee-based activities in Indian banks. International Journal of Research in IT \& Management, 1(1).

Vickers, J. (2011a). Interim Report: Consultation on Reform Options. In: Banking Ico (Ed.).

Vickers, J. (September 2011). The Independent Commission on Banking Final Report Recommendations.

\section{Appendix}

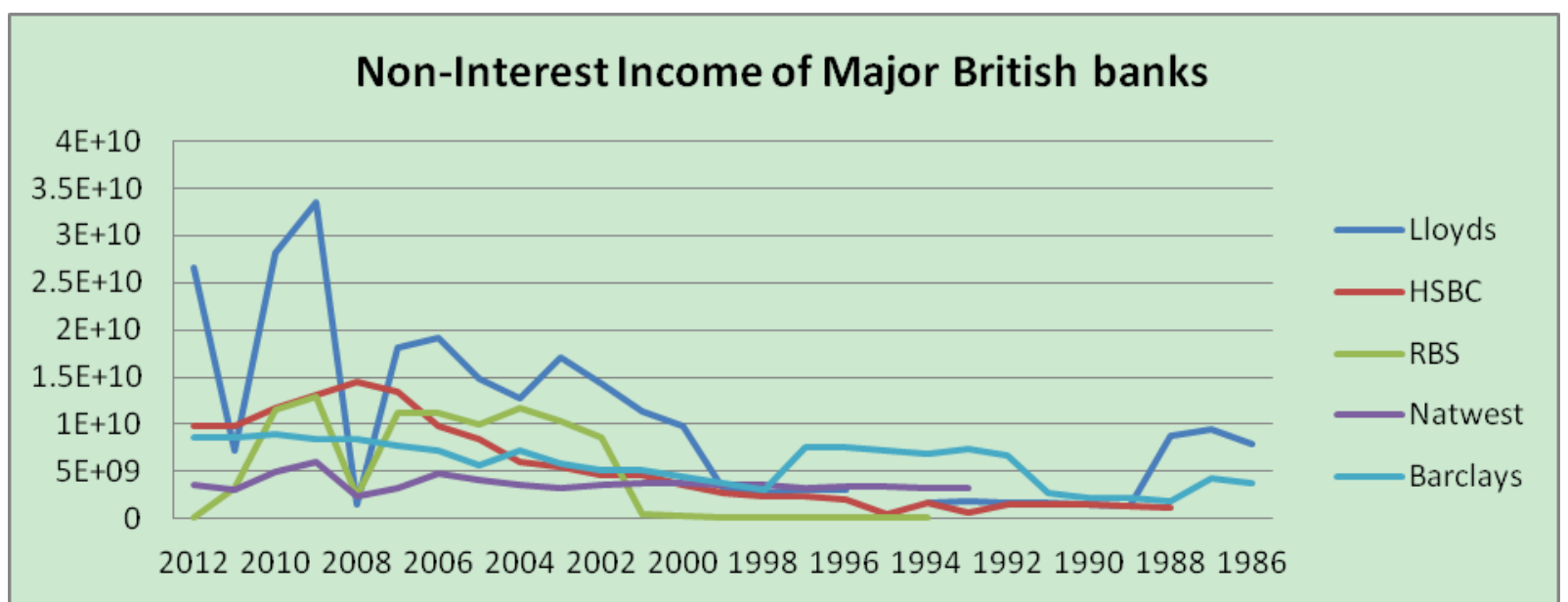

Figureure 3. Noninterest income British banks from 1986-2012 


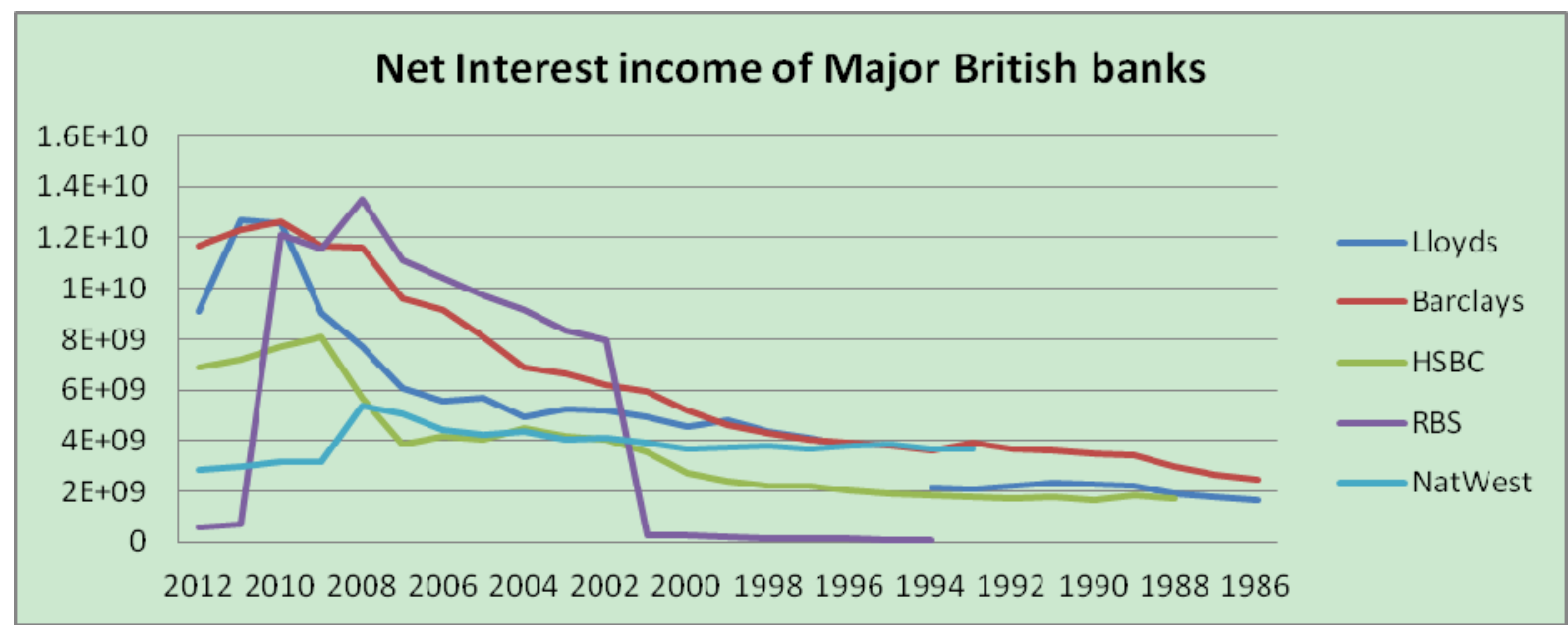

Figure 4. Interest income of British banks from 1986-2012

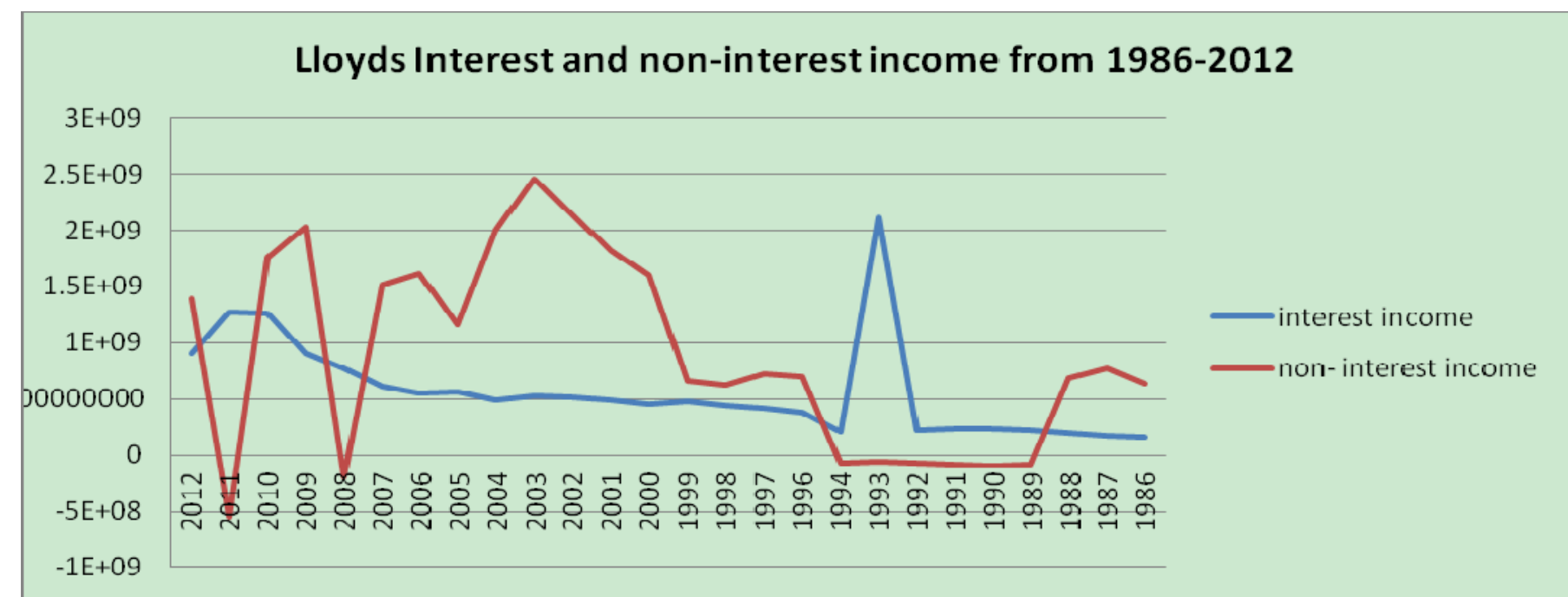

Figure 5. Lloyds Interest and non-interest income from 1986-2012

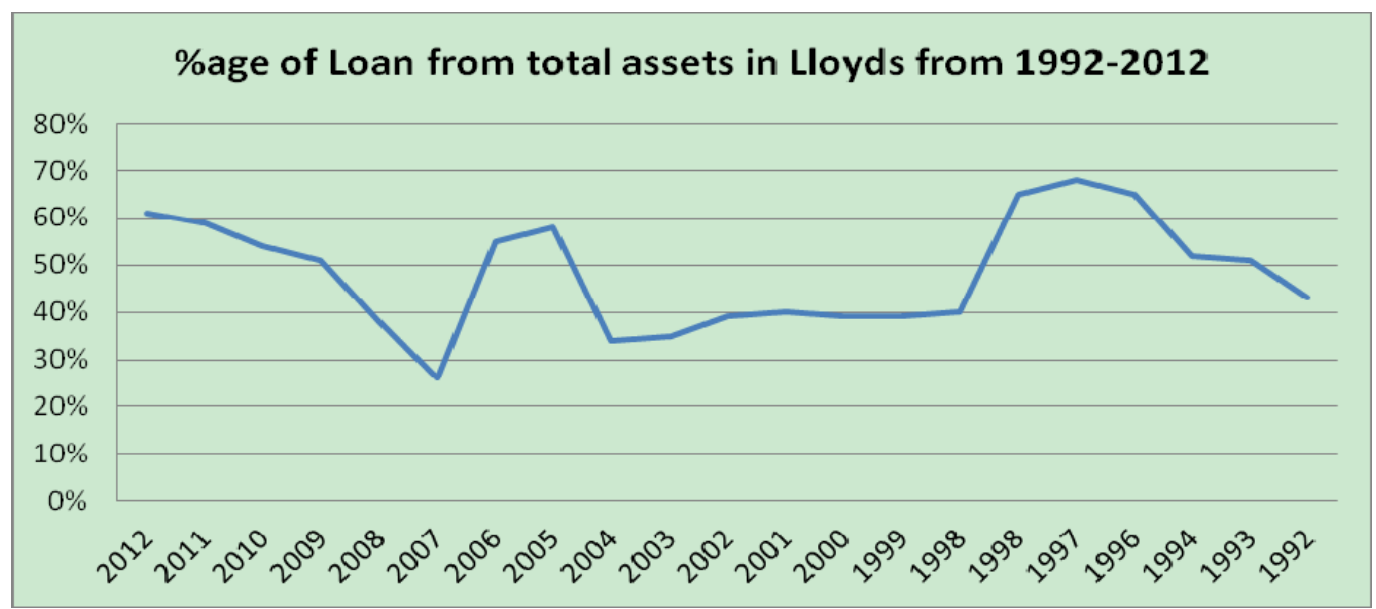

Figure 6. Percentage of Loans from total assets in Lloyds from 1992-2012 


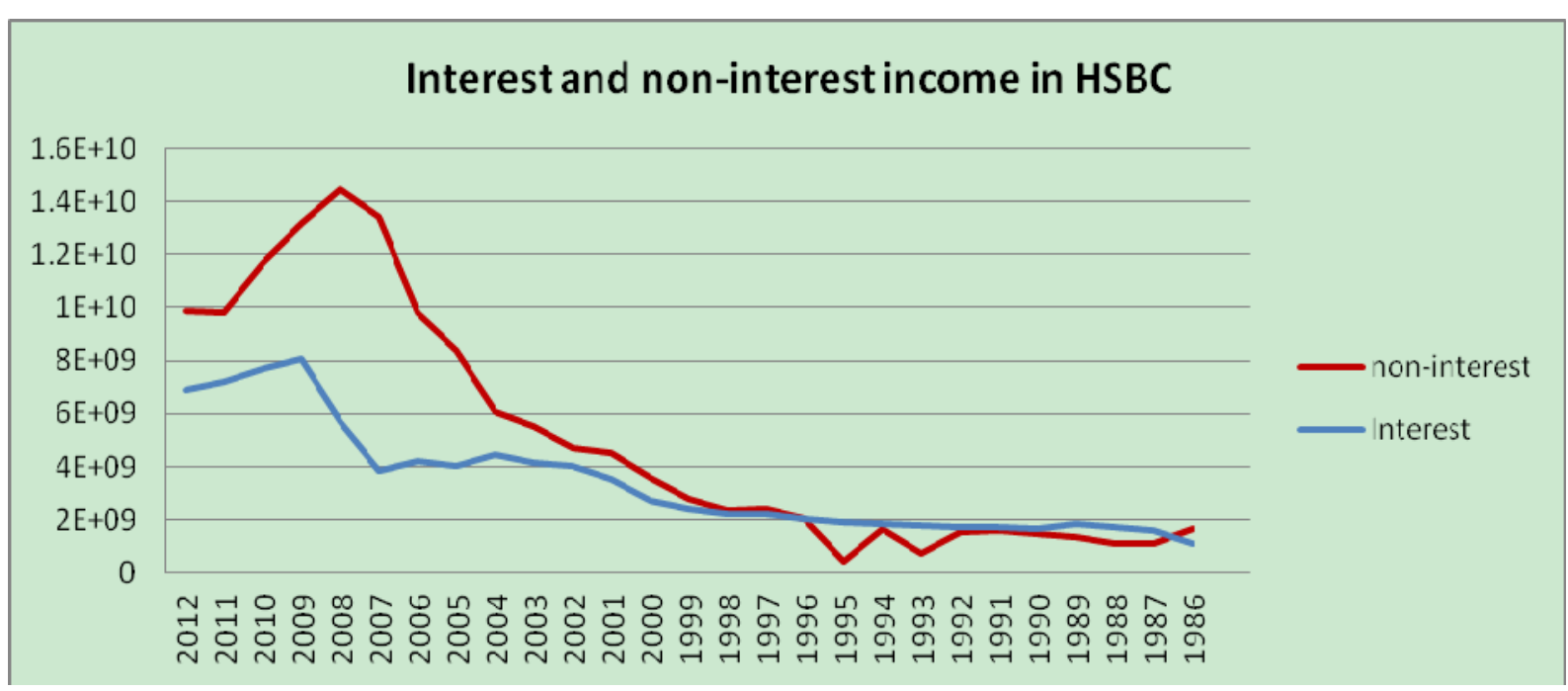

Figure 7. Interest and Noninterest income in HSBC

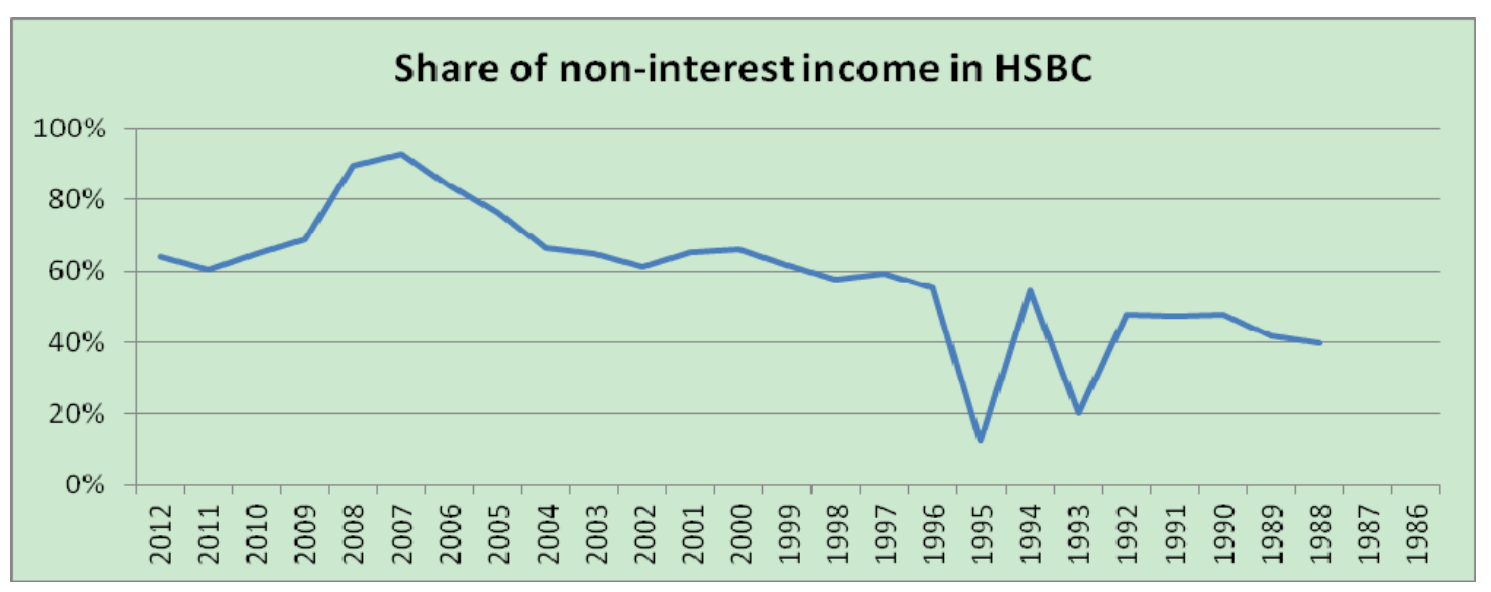

Figure 8. Share of noninterest income in total income in HSBC from 1988-2012

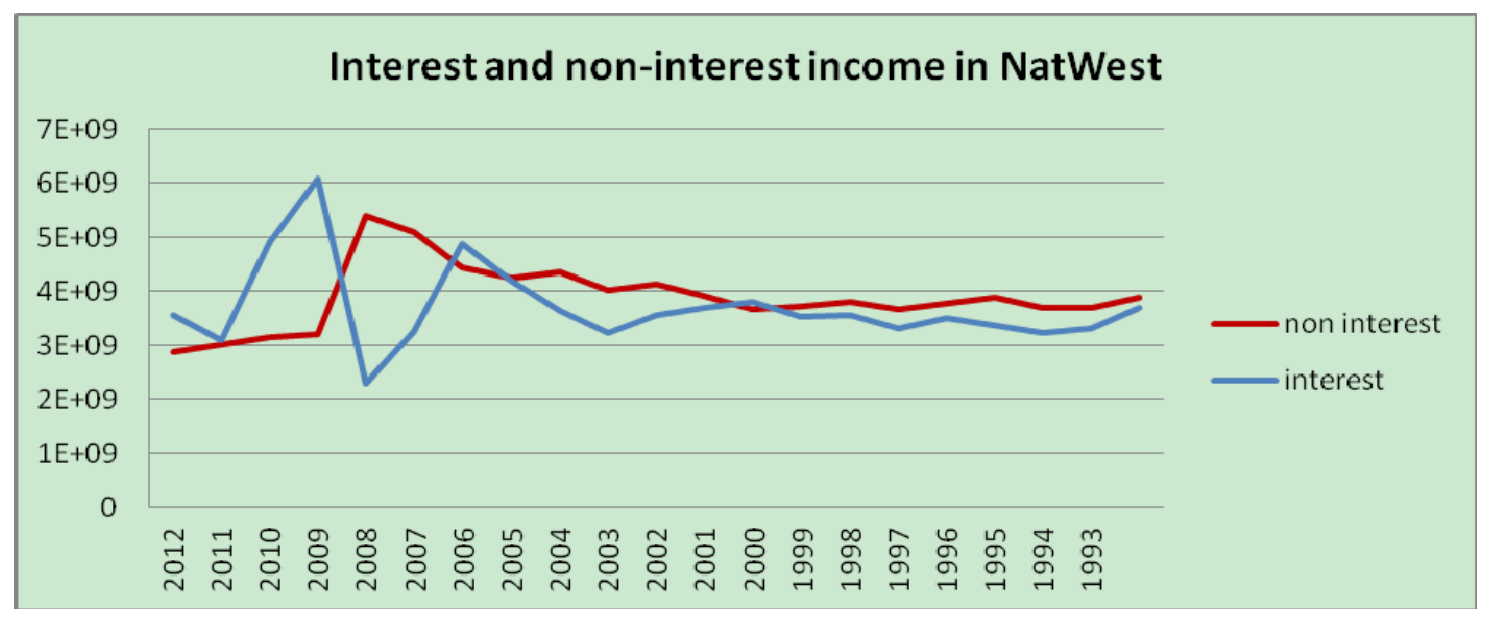

Figure 9. the interest and noninterest income of NatWest from 1986-2012 


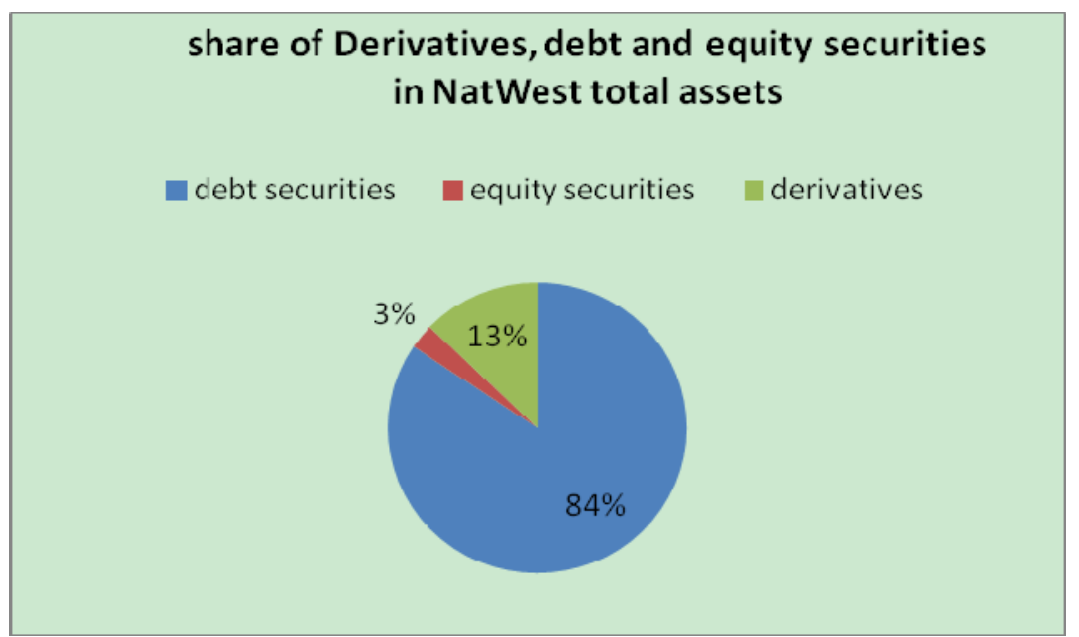

Figure 10. The share of derivatives, debt and equity securities in NatWest from 1993-2006

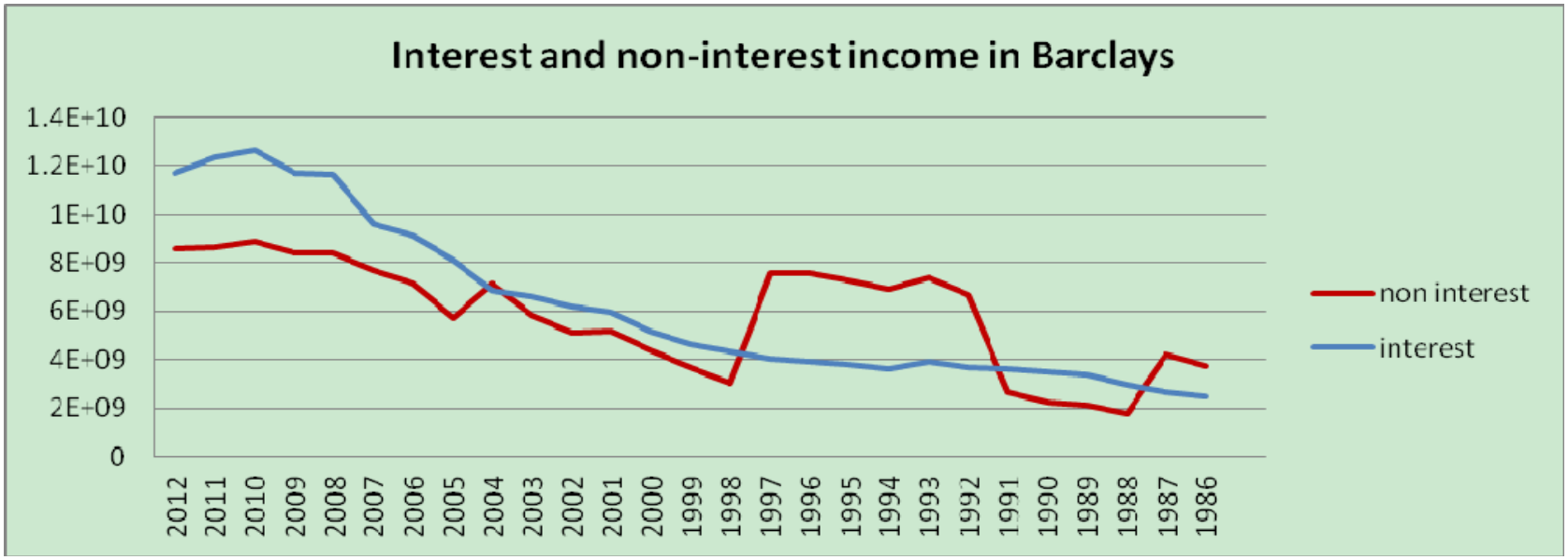

Figure 11. Interest and noninterest income in Barclays 1986-2012

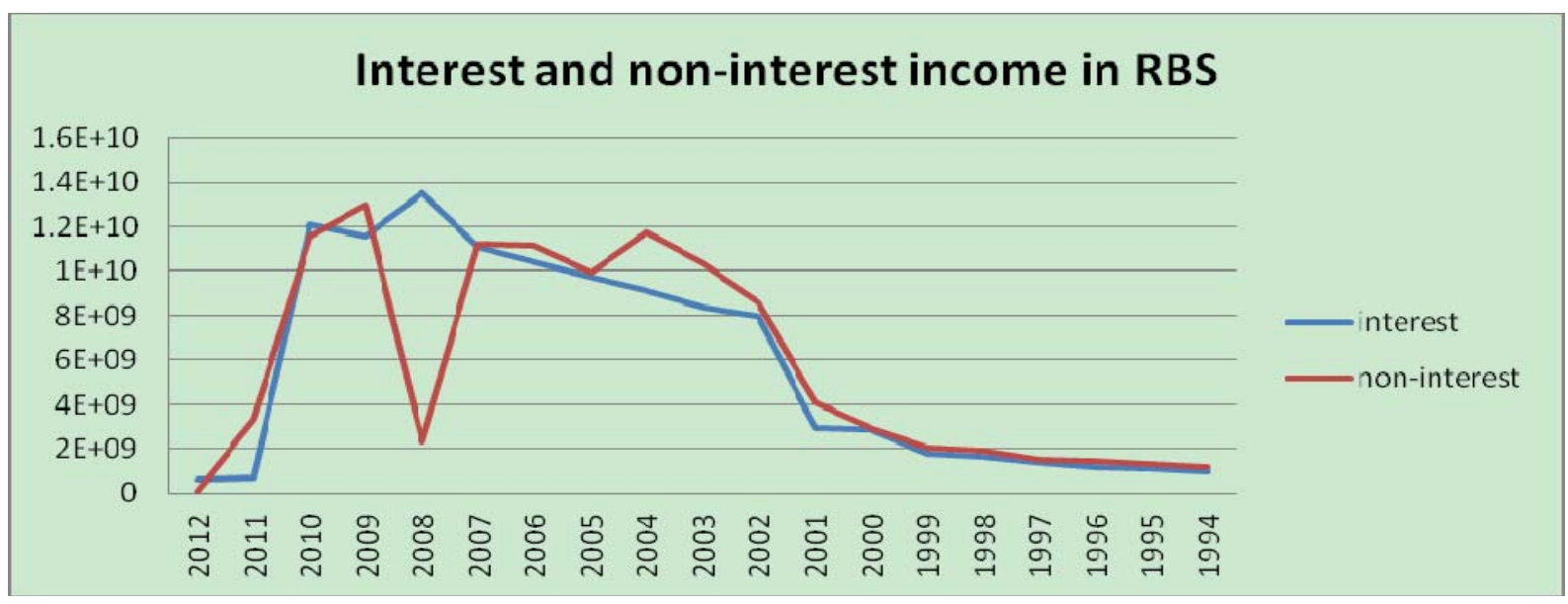

Figure 12. Interest and noninterest income of RBS from 1994-2012 